\title{
Estimation of Tourism Demand and Supply Functions for Azerbaijan: 2SLS Approach
}

\author{
GULALIYEV G. MAYIS \\ Mingachevir State University, Mingachevir city, \\ D. Aliyeva 21 AZ4500, AZERBAIJAN \\ https://orcid.org/0000-0001-7614-7322 \\ GULIYEVA T. SHAFA \\ Azerbaijan State University of Econmics (UNEC). AZERBAIJAN \\ HAJIYEVA A. LEYLA, PhD \\ Azerbaijan State University of Economics (UNEC), AZERBAIJAN \\ MURADOVA R. HIJRAN, PhD \\ Azerbaijan State University of Economics (UNEC), AZERBAIJAN \\ MAMMADOVA I. ULKER \\ Institute of Economics of Azerbaijan National Academy of Sciences, \\ Baku city, ave. H.Javid, 115. AZ1143, AZERBAIJAN
}

\begin{abstract}
In this paper, there was investigated tourism demand and supply functions in the case of Azerbaijan. The authors have applied the 2SLS method to identify these functions. The authors came to the conclusion that the demand function of tourist trips to Azerbaijan varies depending on the level of income of tourists' origin countries and the price level in Azerbaijan. Unfortunately, the COVID-19 pandemic impacts not only the restriction policy of origin countries, as well as income in these countries. By decreasing the income levels of the population in these countries will be decreased the number of tourists to Azerbaijan.
\end{abstract}

Key -words: Demand function, supply function, tourism sector, 2SLS, COVID-19, price index

Received: March 12, 2021. Revised: September 25, 2021. Accepted: October 15, 2021. October 20, 2021.

\section{Introduction}

Investing in services can increase both 'demand' and 'supply'. One of the distinguishing features of investment in services is that they are closely related to other areas. Therefore, investments in the service sector indirectly affect other areas. The service sector is more important in eliminating unemployment as it covers more small and medium enterprises Lea J.[1], Samimi A. et al.[2], Sinclair T. [3]. Efficiency of small and medium enterprises increases due to better competition environment.

The development of international service trade requires capital, infrastructure, knowledge and skills, access to the global market and the sharing of values. In particular, access to finance is critical to the development of international service trade and economic growth. Therefore, foreign direct investment can play an important role as a source of funding for the development of international service trade.

Tourism is playing an increasingly important role in international economic relations. International tourism spending nearly tripled from $\$ 500$ billion to \$ 1.6 trillion between 1995 and 2014 [4]. This increase is not only due to changes in the value of the dollar. It is also due to the sharp increase in the number of visitors. During this period, the number of tourists increased from 600 million to 1.5 billion (about three times). The decline in the share of tourism revenues in total exports during those years does not mean a decrease in the economic importance of tourism. Thus, the decline in the share of tourism in recent years has taken place against the background of a sharp increase in exports of goods and services around the world.

Although the widespread of the COVID-19 pandemic since early 2020 has dealt a serious blow 
to the tourism industry, it is undoubtedly the most promising area of economic activity in the future. Because tourism is connected with the well-being of people. People try to consume more, spend less time at work, integrate more with nature, and get acquainted with the material and spiritual cultures of other countries. All this motivates people to travel to other countries as tourists. Any economic, epidemiological, military, natural and other events may limit tourism activities in a country for a short period of time. Although the Covid-19 pandemic has limited international ties for some time, such restrictions are expected to be short-lived, and tourism will resume once global vaccinations are in place. As we have noted, the demand for tourism is based on improving people's welfare, accelerating and reducing the cost of international movement as a result of scientific and technological development, expanding ties due to the development of communication technologies and integration of the world economic system.

Despite its ancient history as an area of economic activity, the number of international tourists has steadily increased over the past 50 years, reaching 1.5 billion in 2019, as a result of the abovementioned reasons for the expansion of demand for tourism. Tourism already has a special share in the competitiveness of countries as a high-income economic activity. That is why research on the demand function of tourism and the determinants on which it depends is expanding since the nineties of the last century Crouch,G. [5], Lee C. et al.[6].

Despite the short-term weakening of demand for tourism in various countries or regions, such as Europe, the overall growth trend continued until the Covid-19 pandemic. In particular, the growing demand for tourism is growing rapidly in the Middle East, as well as in Asia and the Pacific.

\section{Literature Review}

The high importance of the tourism industry in economic development, as well as some problems related to tourism have drawn the attention of researchers over the past 50 years. Among these problems there are some problems related with the impact of tourism on economic growth, socioeconomic spheres, including poverty reduction, income inequality, employment and other issues. The study of the demand and supply function of tourism and the determinants that affect them, the impact of fiscal and monetary policy on these determinants and the problems of state regulation of tourism as a whole are also in the focus of researchers.
Tourism, as a type of economic activity, has both a demand and a supply function. As an indicator of demand function, it is possible to take the number of tourists willing to benefit from tourism services in the destination country, as well as the amount of expenses in this country and other indicators. In the host country, tourists are offered a variety of goods and services. The readiness of tourists to purchase these goods and services, in addition to determining the demand, depends on the income of these tourists, the price level in the country and other indicators.

The importance of defining the demand function of tourism for each country is a great scientific and practical importance in terms of assessing and forecasting the role of tourism in economic development. Among the studies conducted over the last 10 years on the calculation of the demand function of tourism, some studies, such as De Vita [7], Balli F. et.al.[8], Lee C. et.al. [9] and others pay special attention to the role of the government policy in the development of tourism, including the business environment in the country. These studies claim that exchange rate, relative prices, per capita GDP, fiscal and monetary policy in the countries affect the number of tourists. Research by Papatheodorou A. et.al [10] shows that economic conditions play an important role among the determinants of the demand function of international tourism. The financial crisis of 2008 also proved that the expansion of monetary policy in the short term has reduced interest rates in some countries to a minimum or even zero. This showed that traditional monetary policy was not effective in stimulating the economy. In a country where traditional monetary policy has not been used as a stimulus, for example, in Japan, there has been a devaluation of the national currency. The effects of the 2008 financial crisis, as well as the Fukushima nuclear plant, on the tourism sector in Japan were investigated by Fukuda [11]. Economist [12], Japan National Tourism Organization [13] and other studies.

Defining the demand function of tourism and the determinants that affect it can allow for a more effective organization of tourism in each country and government intervention in the tourism sector. It should be noted that many empirical studies on the impact of tourism on economic growth, (for example, De Vita \& Kyaw [14], Yanling Ma [15], Tzu-Kuang Hsu \& I-Hsun Tsai [16], Brida J.et.al. [17], Tang C. \& Tan E. [18]) show the tourism industry has a positive impact on economic growth, employment, tax revenues, national income, as well as value added in other areas of economic 
activity indirectly related to tourism. According to research conducted by Dogru T. \& Bulut U.[19] tourism has played an important role in economic recovery since the 2008 financial crisis. In the studies conducted by Mahadevan R.et al. [20] and Kinseng R. et.al [21] argue the positive effects of tourism on economic growth in Indonesia, but negative effects, such as increased income inequality, environmental pollution, and cultural problems.

Various determinants affecting the demand function of tourism have been outlined by different researchers. For example, in the research conducted by Habibi F. [22] there was distinguished economic and non-economic determinants that affect the demand function of tourism. Gallego A. et.al. [23]; Kim J. et.al. [24]; Liu A. et.al [25]; Wray M. [26] and others include some indicators such as government regulation, transport technologies, the real exchange rate, international economic relations, and so on as determinants that affect the demand function of tourism.

The impact of the Covid-19 pandemic on the tourism sector is being felt in every country. Restrictions on countries, especially in services, have weakened international trade and travel links, and the shift to distance learning has resulted in lower household incomes and the cessation or weakening of small and medium-sized enterprises (SMEs). Covid-19 is still ongoing and it is unclear when it will end. In this case, the problem of providing the tourism sector, international trade and services "together" with the Covid-19 pandemic and adapting to such shocks becomes more and more urgent.

Research into the impact of the Covid-19 pandemic on various sectors of the economy, especially the tourism sector, is becoming more common. Such studies are still primarily related to impact assessment and mitigation. There is still little academic research in Azerbaijan on the macroeconomic consequences of the Covid-19 pandemic, including in the tourism sector.

Undoubtedly, the economic consequences of the Covid-19 pandemic are so serious that the various aspects of problem are studied by the World Bank and other international organizations, as well as by well-known economic research centres such as the Heritage Foundation, The Economist Intelligence Unit and others. Currently, reports on the macroeconomic and socio-economic impact of the Covid-19 pandemic are being prepared and published at various levels in every country. These reports look at declining GDP by country, rising unemployment, declining household incomes, declining international trade, a virtual halt in international trade in services, especially tourism, the decline of small and medium-sized enterprises, and other problems. For example, the World Bank [27] estimates that 11 million people in the AsiaPacific region will find themselves in poverty as a result of the Covid-19 pandemic. A study by Buheji K. et al. [28] predicts that 49 million people on four continents (Asia, Africa, South America and Europe) with daily incomes of less than US \$ 1.9 will end up in extreme poverty.

Comparative analysis of numerous studies on the macroeconomic impact of the Covid-19 pandemic shows that developing countries are more vulnerable to such pandemics and similar shocks than developed countries. Because in such countries there is less financial capacity to ensure a minimum standard of living for the population. In developing countries, household savings are lower. The amount of compensation paid to the population and to the small and medium-sized businesses, due to the restrictions, imposed by such countries, on the Covid-19 pandemic, is much lower than in developed countries. To study this problem, extensive scientific research is being carried out in different countries. For example, the impact of the Covid-19 pandemic on small and medium-sized businesses has been studied by Fairlie [29], Bartik A.et al.[30], Bohn S. et al. [31], Orozco, M. et al.[32] and other researchers and institutions.

\section{Methodology}

Various indicators are used to assess the tourism sector development in different countries. The most important of these indicators are: a) The number of incoming tourists; b) Number of tourists leaving; c) Tourism revenues; d) Tourism expenses; e) Number of local tourists; f) The share of tourism expenditures in total imports; h) The share of tourism revenues in total exports.

The rapid development of international tourism makes it necessary for the state to pay attention to this sector in every country. As noted above, in most countries, both the "demand" and "supply" components of tourism face active government intervention. The generalization of a large number of studies devoted to the study of tourism allows us to distinguish the following as its main determinants:

$$
D_{t}=F\left(P_{t} ; S_{1, t}, S_{2, t} \ldots S_{n, t} ; C_{t} ; \dot{I}_{t} ; V_{t} ;\right)
$$


Here, $\mathrm{P}_{\mathrm{t}}$ - is the price parity index in the country. In a country with a high parity index, the demand for tourism may tend to increase. The parity index is usually higher in developing countries than in developed ones. $\mathrm{S}_{\mathrm{i}, \mathrm{t}^{-}}$indicates the replacement of tourist trips to the country with tourist trips to other countries for one reason or another. For example, tourist trips to Azerbaijan may be replaced by trips to other countries of a similar nature due to differences in price and quality of service. One such country could be Georgia or Turkey. In this case, $\mathrm{S}_{\mathrm{i}, \mathrm{t}^{-}}$represents the tourism costs in those countries. According to preliminary considerations, as the price of tourism services in these countries increases, the demand for tourism services in Azerbaijan may increase. $\mathrm{C}_{\mathrm{t}^{-}}$is a market price index. As living costs and market prices rise in the country, this is reflected in the demand for tourism. According to preliminary considerations, inflation has a negative impact on demand. $\dot{I}_{\mathrm{t}}$ - represents the amount of income. According to preliminary considerations, the increase in average incomes in the country can have a positive effect on the growth of domestic tourism and tourist trips abroad, and to some extent positive, and then negatively affect the number of tourists visiting the country. Thus, tourists are reluctant to travel to poor countries. In developed countries, high prices increase the cost of tourist trips. $\mathrm{V}_{\mathrm{t}^{-}}$begins with difficulties in issuing visas. The ease of the visa regime has a positive effect on the number of tourists visiting the country. Thus, most of the determinants that affect the level of demand can be considered the existing economic environment for the tourism sector. For example, changes in the general price level, which can have a serious impact on tourism, require extensive government intervention in the economy. Also, another factor influencing the demand for tourism $S_{i, t}$ is not directly dependent on the level of government intervention in the i-th country, as it is related to the current economic situation in the other country. In order to increase competitiveness in the field of tourism, the i-th country should try to create favourable conditions for tourists, always keeping in mind the price level in the $\mathrm{j}$-th rival country. However, this measure also requires wider government intervention in the economy or wider liberalization. Among the determinants discussed above, only the determinant $V_{t}$ related to the visa regime is directly related to tourism. By changing the visa regime, the state can directly affect the demand for tourism.

When we say supply for tourism, we mean the volume of domestic product created in the country in the field of tourism services and tourism-specific activities. The supply function for tourism activities can be expressed as

$$
\mathrm{S}_{\mathrm{t}}=\mathrm{F}\left(\mathrm{H}_{\mathrm{t}} ; \mathrm{R}_{\mathrm{t}} ; \mathrm{T}_{\mathrm{t}} ; \mathrm{INV}_{\mathrm{t}} ; \mathrm{EF}_{\mathrm{t}} ; \mathrm{TB}_{\mathrm{t}}\right)
$$

Here, $\mathrm{H}_{\mathrm{t}^{-}}$hotels and similar enterprises in the country, $\mathrm{R}_{\mathrm{t}}$ - restaurants and similar establishments, $\mathrm{T}_{\mathrm{t}}$ - number of travel agencies and tour operators, $\mathrm{INV}_{\mathrm{t}^{-}}$is the volume of investments in the tourism sector in the country, $\mathrm{EF}_{\mathrm{t}}$ - level of sectoral state intervention; $\mathrm{TB}_{\mathrm{t}^{-}}$tax burden. All these determinants are directly influenced by the state. Since the supply function of the tourism sector is more dependent on the first three variables that are dependent on the fourth, we can characterize the supply function as an investment-dependent function. The volume of investments in the tourism sector is also related to the favourable business environment in this sector. Therefore, the optimal level of government intervention in the tourism sector can be determined by assessing the relationship between the volume of supply in the tourism sector and investments in this area, the level of sectoral government intervention and tax incentives.

As we have noted, one of the main differences between international tourism services and other types of economic activities is that international tourism services depend on both domestic and foreign factors. The development of these factors ensures the country's competitiveness in the field of tourism. With the development of these factors, each country is trying to regulate tourism. These factors indirectly affect the supply and demand functions of tourism. So it is necessary to define these functions.

We will use the 2SLS method to assess the demand and supply functions of the tourism sector in Azerbaijan. In this case, we will only take the GDP per capita in the tourist country and the consumer price index in the local country as the main factor influencing the demand function of tourism, the price index as the factor influencing the supply function and the price index in any of the neighbouring countries.

Given the above, for simplicity, we will assume that demand in the tourism services market (TD) may vary depending on the income of the population in the local tourist country. Unlike other goods, tourism services in Azerbaijan can be replaced by services in a neighbouring country, such as Georgia. Thus, for simplicity, we will express the demand function in the tourism market in Azerbaijan as a function dependent on two variables - the price 
index (PPP) and the level of income in tourist countries (OGDPPC):

\section{Demand:}

$T D_{i t}=a+b_{1} * P P P_{i t}+b_{2} * O G D P P C_{i t}+e_{d}$

(3)

Supply:

$T S_{i t}=c+d_{1} * P P P_{i t}+d_{2} * S U B P P P_{i t}+e_{s}$

Here, $T D_{i t}=T S_{i t}=Q$, and $O G D P P C_{i t}$ is real GDP per capita in the tourist country, $S U B P P P_{i t}$ is price index in the substitute country, (i.e. in Georgia for our case). The price index in substitute country is an exogenous indicator for the supply function. PPP it is an endogenous indicator for both functions. According to economic theory, $b_{1}<0 ; d_{1}>0$ we will accept. $e_{d}$ və $e_{s}$ are random errors and the following restrictions apply to them:

1) $\left.\quad \mathrm{E}\left(e_{d}\right)=0 ; 2\right) \quad \operatorname{var}\left(e_{d}\right)=\sigma_{d}^{2} ; \quad \mathrm{E}\left(e_{s}\right)=0$; $\operatorname{var}\left(e_{s}\right)=\sigma_{s}^{2} ; \operatorname{Cov}\left(e_{d}, e_{s}\right)=0$

"Simultaneous equation model" can be shown for $P P P_{i t}$ by using,

Or

$$
\begin{gathered}
P P P_{i t}=\frac{a-c}{d_{1}-b_{1}}+\frac{b_{2}}{d_{1}-b_{1}} * O G D P P C_{i t}-\frac{d_{2}}{d_{1}-b_{1}} * \\
S U B P P P_{i t}+\frac{e_{d}-e_{S}}{d_{1}-b_{1}}
\end{gathered}
$$

Q while for

$$
\begin{array}{r}
P P P_{i t}=\pi_{11}+\pi_{12} * O G D P P C_{i t}+\pi_{13} * \\
S U B P P P_{i t}+\varepsilon_{p}
\end{array}
$$

$$
\begin{array}{r}
\mathrm{Q}=\frac{a * d_{1}-b_{1} * c}{d_{1}-b_{1}}+\frac{b_{2} * d_{1}}{d_{1}-b_{1}} * O G D P P C_{i t}-\frac{b_{1} * d_{2}}{d_{1}-b_{1}} * \\
S U B P P P_{i t}+\frac{d_{1} e_{d}-b_{1} e_{S}}{d_{1}-b_{1}}
\end{array}
$$

or

$\mathrm{Q}=\pi_{21}+\pi_{22} * O G D P P C_{i t}+\pi_{23} *$

$S U B P P P_{i t}+\varepsilon_{q}$

Based on "Simultaneous equation model", we will use the two-level least squares method (2SLS). Necessary information for the research is provided by the State Statistics Committee of Azerbaijan [33] and obtained from the official website of the World Bank.

\section{Results}

\subsection{Tourism in Azerbaijan (Currents Situation)}

Although oil and gas revenues play an important role in Azerbaijan's foreign exchange earnings, special attention is paid to the development of other sectors, especially the service sector. In recent decades, the liberalization of the country's economy (Gulaliyev M. et al, [34]) and the development of human capital (Gulaliyev M. et al, [35]) have laid a good environment for the development of the service sector, including tourism.

Before moving to government regulation of the factors affecting supply and demand in the field of tourism, we try to make a comparative analysis of the current situation in the field of tourism in accordance with the level of income of countries. So, let's divide the countries according to the income level into 5 main groups (low, low-middle, middle, upper middle and high-income countries) and compare the level of tourism development in these groups. The Graph 1 shows the dynamics of the number of tourists leaving the country in groups over the past 20 years. The fact that in subsequent years, compared to 1995, the number of tourists in each income group countries shows that this economic sector is in the interest of each country.

The significant correlation between the number of tourists leaving the country and the country's GDP per capita shows that as the population's income increases, so does the number of tourists. It is connected with increasing welfare level, especially of increasing of leisure time. However, it should be borne in mind that high incomes are not the only factor for tourist trips. As mentioned above, there are other factors for tourist trips. At the very least, it can be assumed that despite the high incomes of the population in some developed countries, more and more people are trying to take advantage of the tourism opportunities available in the country. For example, although North America, as well as the United States and Australia, have high incomes, the share of foreign tourists from these countries is lower than in Albania, Poland, Hungary, and many other low-income countries. The same situation can be observed in Japan. The share of international travellers from this country is even smaller than Laos.

The number of tourists visiting the country also depends on the income groups of the countries. Thus, the number of tourists visiting high-income countries is much higher than other groups. An important point in the Graph 2 is that the number of foreign tourists visiting middle-income countries is much higher than the number of tourists visiting upper-middle-income countries. Although the latter have high incomes, the number of tourists is small compared to the former. Empirical studies conducted in different countries also show that the number of tourists visiting the country and its share in the population does not depend on the amount of per capita income in the country. This allows us to 
conclude that the attraction of tourists to the country does not depend on the overall level of development of the country.

It should be noted that the share of tourism revenues in GDP of Azerbaijan was around 5\% in 2015 and $6 \%$ in 2018. Thus, according to the World Bank in

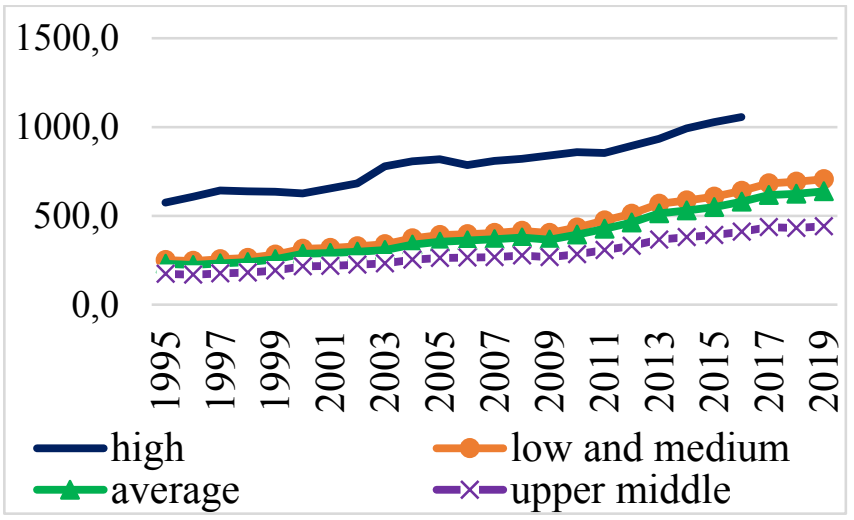

Fig. 1: Dynamics of the number of outgoing tourists (mln. people) by income groups of the countries

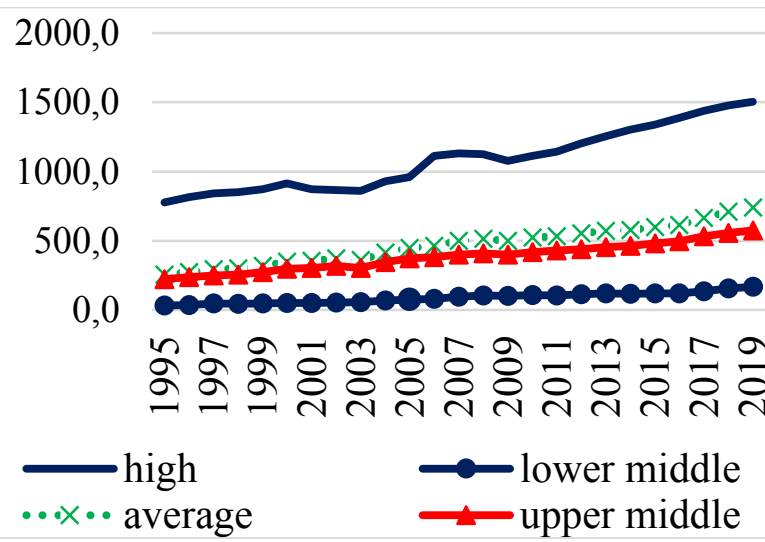

Fig. 2: Dynamics of the number of incoming tourists (mln. people) by income groups of the countries

The main turning point in the development of tourism in Azerbaijan began in 2012. Until now, Azerbaijan has lagged behind the world average in key indicators of tourism development. Since 2012, there has been a sharp increase in the number of tourists visiting the country and the amount of income and expenditure from tourism. For example, in Azerbaijan, in terms of "share of tourism expenditures in imports" and "share of tourism expenditures in exports", "share of tourism revenues in GDP", "share of the number of tourists in the population", Azerbaijan had
2015, Georgia's tourism revenues amounted to $\$ 2.1$ billion, while Azerbaijan's revenues amounted to $\$$ 2.5 billion. However, due to the fact that Azerbaijan's revenues from other economic activities are much higher than those of Georgia, the share of tourism revenues in GDP is small.

small values in comparison with world average before 2012 (Graph 3-6).

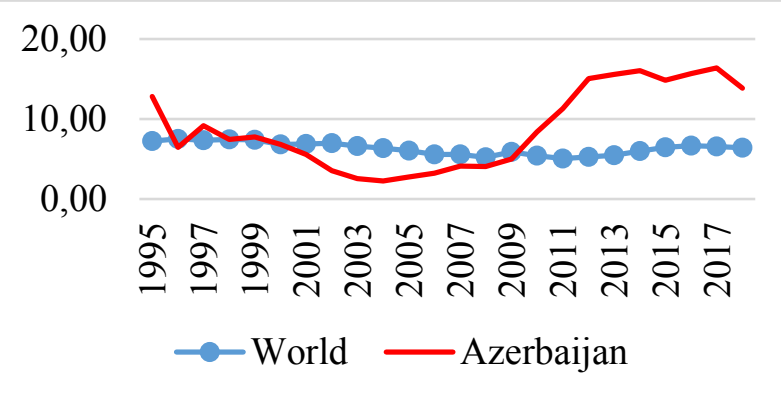

Fig. 3: Share of tourism expenditures in imports in Azerbaijan and in the world (\%)

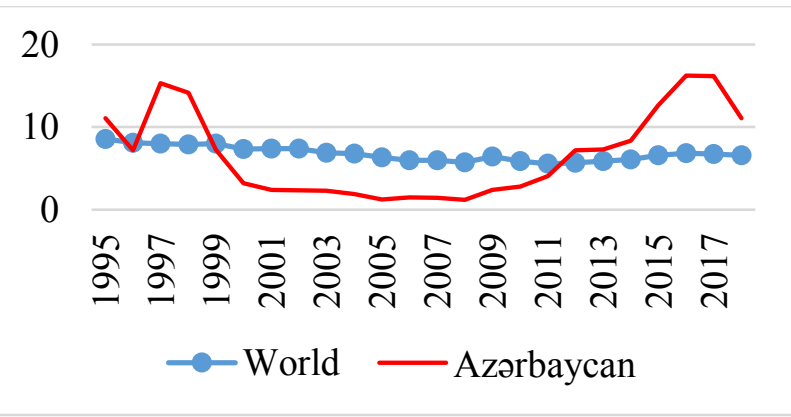

Fig. 4: Share of tourism revenues in exports in Azerbaijan and in the world (\%)

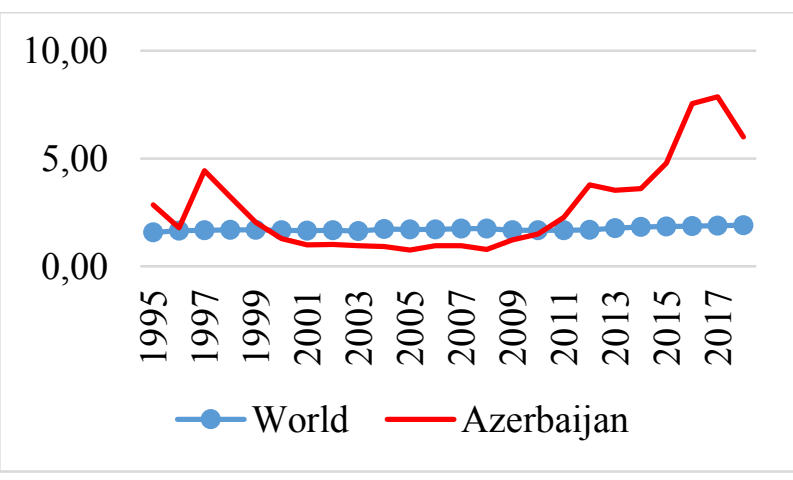

Fig. 5: Share of tourism revenues in GDP in Azerbaijan and in the world (\%) 


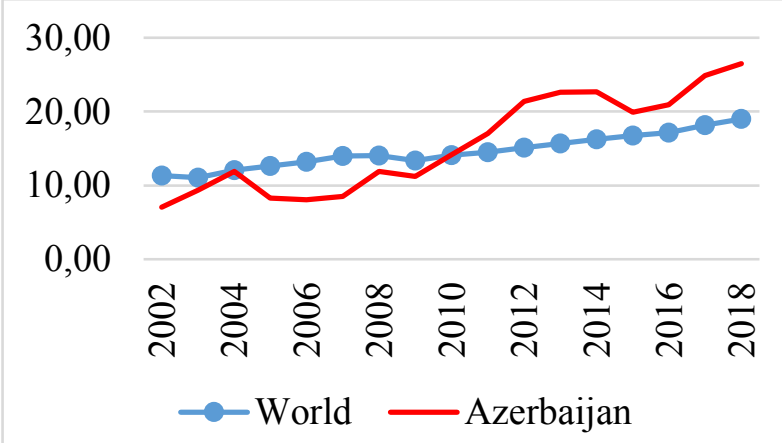

Fig. 6: Proportion of the number of tourists visiting the country in Azerbaijan and in the world (\%)

It should be noted that due to the rapid development of the tourism industry in Azerbaijan in recent years (before COVID-19), there are not many travel agencies and tour operators that offer these services. The number of such enterprises in 2006 was 96 . However, in the following years, their number increased until 2020 and reached 432. However, this is very low compared to countries with a large tourism industry. Only two of them are state-owned. The remaining enterprises are private. There are various reasons for the small number of travel agencies and tour operators in Azerbaijan. The main reason, of course, is the low demand for their activities. In fact, there is a serious disproportion between the number of tourists visiting the country and the number of such enterprises. Very few domestic tourists use the services of travel agencies and tour operators. It should be noted that the number of those who go abroad as tourists and recreation is not small. For example, the number of people visiting Georgia through tour operators or travel agencies is much lower than the number of free tourists visiting the country.

We see the same picture in the difference between the number of visitors to Azerbaijan for different purposes and the number of tourists received. In this case, there are significant differences between the indicators. The common denominator in the dynamics of these two pairs of indicators is that until 2014, the number of people coming to or leaving Azerbaijan for tourism or any other purpose had an increasing dynamic, and in subsequent years decreased.

It should be taken into account that the number of tourists visiting Azerbaijan in the last 20 years (until COVID-19) is much less than the number of tourists leaving Azerbaijan (Graph 8). Such differences create a negative balance in the tourism market of Azerbaijan and increase Azerbaijan's tourism expenditures year by year (Graph 7).

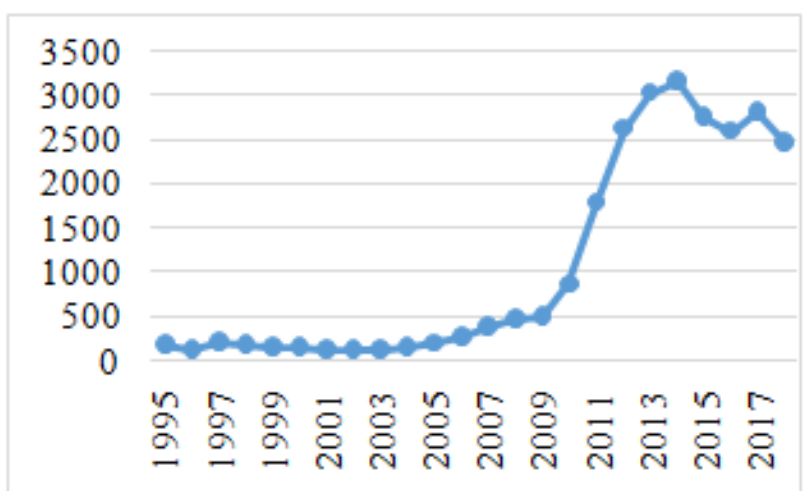

Fig. 7: Tourism expenses in Azerbaijan (thousand USD)

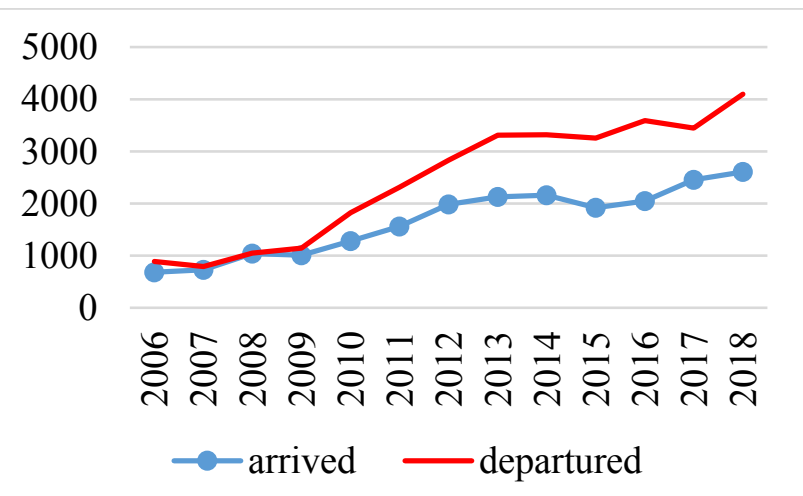

Fig. 8: Number of received tourists (thousand)

\subsection{The Relationship between the Demand Function of Tourism and Its Determinants}

The dynamics of the number of foreigners arriving in the country for different purposes and the number of tourists received and accommodated by tour operators had the same trend during the study period (i.e. 2007-2016). But accepting data from tour operators or travel agencies as important data for the overall tourism demand function is wrong. It is more correct to take the number of tourists coming to the country as a whole, rather than the number of tourists who arrived in the country by tour operators and travel agencies. Because many tourists in Azerbaijan do not use the services of tour operators due to the high cost. In addition, many tourists, especially from Arab countries, come with families and prefer to move around freely. Many tourists, especially from Turkic-speaking or Russianspeaking countries, i.e. from countries that were part of the former Soviet Union, can freely communicate with the local population and do not need special assistance from travel agencies. Because the main 
part of foreign tourists coming to the country are free tourists. According to SSCRA (2021), a significant part of tourists visiting Azerbaijan in 2019 are citizens of Russia, Georgia, Turkey, Iran, Saudi Arabia, UAE, India, Ukraine, Turkmenistan, Iraq, Kazakhstan and Israel. Most of those who come to the country for various purposes are from these countries. It should be noted that people from some of these countries, such as Turkey, Russia, Georgia, Ukraine and Iran, often do not use the services of tour operators and prefer to travel freely, as there are no communication problems. The number of tourists from developed countries and further distances is not so great.

According to our chosen methodology, as well as according to (3) and (4) equations, we will take as the main determinants of the demand and supply function of tourism in Azerbaijan 1) the world average real GDP (OGDPPC $\left.{ }_{i t}\right)$ (2010 base year), 2) the purchasing power parity index in Azerbaijan $\left(\mathrm{PPP}_{\text {it }}\right)$ and 3$)$ the purchasing power parity index in Georgia $\left(S U B P P P_{i t}\right)$, which competes with Azerbaijan in tourism sector.

\subsection{Tourism Demand Function for Azerbaijan}

As a result of the application of the "Simultaneous equation" model for Azerbaijan on the basis of equations (3) and (4), a reduced form for the price in the tourism market was obtained as in Table 1.

Table 1. "Reduced Form" of the number of tourists coming to Azerbaijan from Arab countries

\begin{tabular}{|c|c|c|c|c|}
\hline variable & Coefficient & Standard error & t-statistics & p-value \\
\hline $\mathrm{c}$ & -12474.69 & 1506.983 & -8.277925 & 0.0000 \\
\hline$O G D P P C_{i t}$ & 1.295044 & 0.118056 & 10.96978 & 0.0000 \\
\hline$S U B P P P_{i t}$ & 3205.671 & 1156.674 & 2.771457 & 0.0182 \\
\hline$R^{2}=0.931414$ & & & & \\
\hline F-statistic $=74.69167$ & & & & \\
\hline
\end{tabular}

Note: calculated by the authors

Based on the results obtained in Table 1, the value of the coefficients is statistically significant and thus we can assume that as exogenous variables $O G D P P C_{i t}$ and $S U B P P P_{i t}$ affect the number of tourists coming to Azerbaijan from Arab countries. According to the results obtained in Table 1, $R^{2}=0.931414$, and the F-statistic is 74.69167 , and the p-value is much smaller than 0.05 .
Table 2 shows the relationship between the domestic prices of Azerbaijan and the origin countries sending tourists to Azerbaijan as exogenous variables $O G D P P C_{i t}$ and $S U B P P P_{i t}$. Based on these results, the free coefficient of panel regression dependence is statistically significant. For this regression dependence, too, $R^{2}=0.889979$, and the p-value is less than 0.05 .

Table 2. Reduced form for the ratio of PPP GNI per capita in Azerbaijan and Arab countries

\begin{tabular}{|c|c|c|c|c|}
\hline variable & Coefficient & Standard error & t-statistics & $\mathrm{p}$-value \\
\hline $\mathrm{c}$ & 1.454291 & 0.158780 & 9.159155 & 0.0000 \\
\hline$O G D P P C_{i t}$ & $6.56 \mathrm{E}-05$ & $1.62 \mathrm{E}-05$ & 4.050985 & 0.0019 \\
\hline$S U B P P P_{i t}$ & 1.454291 & 0.158780 & 9.159155 & 0.0000 \\
\hline$R^{2}=0.889979$ & & & & \\
\hline F-statistics $=44.49043$ & & & & \\
\hline
\end{tabular}

Note: calculated by the authors

Based on identity (4) for $\widehat{P P P_{l t}}$ we can find

$$
\widehat{P P P_{l t}}=1.454291+6.56 \mathrm{E}-05 * O G D P P C_{i t}+
$$
$1.454291 * S U B P P P_{i t}$
Thus, by using the values obtained from identity (9) for identity $\widehat{P P P_{l t}}$ in identity (3), we can find the demand function for tourists coming to Azerbaijan from Arab countries.

Table 3. The demand function of tourism from Arab countries for Azerbaijan according to the 2SLS model

\begin{tabular}{|c|c|c|c|c|}
\hline variable & Coefficient & Standard error & t-statistics & $\mathrm{p}$-value \\
\hline $\mathrm{c}$ & -10605.47 & 1055.420 & -10.04858 & 0.0000 \\
\hline$\widehat{\widehat{P P P_{l t}}}$ & 2204.271 & 795.3474 & 2.771457 & 0.0182 \\
\hline
\end{tabular}




\begin{tabular}{|l|l|l|l|l|}
\hline \multicolumn{1}{|c|}{$O G D P P C_{i t}$} & 1.150444 & 0.094135 & 12.22118 & 0.0000 \\
\hline$R^{2}=0.931414$ & & & & \\
\hline $\mathrm{F}=74.69167$ & & & & \\
\hline
\end{tabular}

Note: calculated by the authors

$$
\begin{array}{r}
T D_{i t}=-10605.47+2204.271 * \widehat{P P P_{l t}} \\
+1.150444 * O G D P P C_{i t}
\end{array}
$$

The demand and supply functions of tourism in Azerbaijan were found by applying the 2SLS method (two-level least squares method) using the following system of mass regression equations:

$$
\left\{\begin{array}{c}
Q^{d}=T D_{i t}=a+b_{1} * P P P_{t}+b_{2} * O G D P P C_{i t}+\varepsilon_{d} \\
Q^{s}=T S_{t}=c+d_{1} * P P P_{t}+d_{2} * S U B P P P_{t}+\varepsilon_{s}
\end{array}\right.
$$

Here, in $A P \dot{\mathrm{I}}_{t}$ and $G P \dot{\mathrm{I}}_{t}$-t, respectively, the price index in Azerbaijan and Georgia, OGDPPC ${ }_{i t}$-tyear, real GDP per capita in the country of origin of the tourist, $G P \dot{\mathrm{I}}_{t} \mathrm{t}$-competition with Azerbaijan in the field of tourism is a price index in the host country, for example, Georgia. With the application of this method, it has been determined for tourists from Middle Eastern countries that,

$$
\begin{aligned}
& \begin{array}{cccccc}
T D_{i t}= & -12474.7 & +1.29 & * \text { *OGDPPC } & +3205.7 & * \text { *SUBPPP } \\
& (1506.983) & (0.118) & & (1156.674) &
\end{array}
\end{aligned}
$$

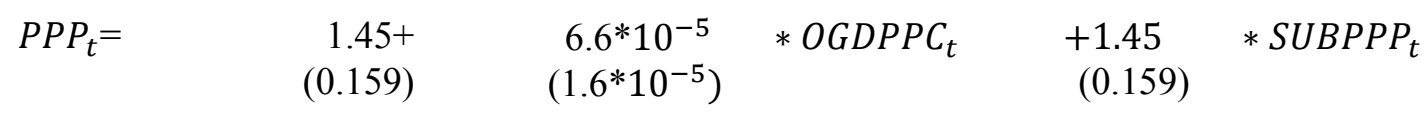

$$
\left\{\begin{array}{c}
\frac{a-c}{d_{1}-b_{1}}=1.45 ; \frac{b_{2}}{d_{1}-b_{1}}=6.6 * 10^{-5} ; \frac{d_{2}}{d_{1}-b_{1}}=1.45 \\
\frac{a * d_{1}-b_{1} * c}{d_{1}-b_{1}}=-12474.7 ; \frac{b_{2} * d_{1}}{d_{1}-b_{1}}=1.29 ; \frac{b_{1} * d_{2}}{d_{1}-b_{1}}=-3205.7
\end{array}\right.
$$

By solve the system of equations (13), we can model the functions of supply and demand for tourism in Azerbaijan as follows:

$$
\left\{\begin{array}{l}
Q^{d}=-370735.97-2210.83 * P P P_{t}+1.437 * O G D P P C_{i t} \\
Q^{s}=-402318.17+19560 * P P P_{t}+31582.2 * S U B P P P_{t}
\end{array}\right.
$$

The construction of tourism infrastructure, including roads, airports and hotels, requires significant funds. Studies, e.g. Selvanathan S. et al [36] show that most developing countries pay special attention to attracting FDI to increase the number of tourists and ensure economic growth. On the other hand, there is a significant correlation between the volume of FDI and the number of tourists. As the volume of FDI increases, the quality of services increases. This leads to an increase in the number of international tourists.

\section{Discussion}

Our conclusions confirm the conclusions obtained by other researchers in the example of different countries. For example, Ruoting Zhang in the example of Wuhan [37], Alegre J., \& Pou, L. [38] in the example of the United States and many other researchers confirm that as the income of the population rises, the decision to go on vacation as tourists increases. Khalid et al, [39] show that crises in origin countries negatively affect tourism demand. Our investigation shows that incomes in Arab countries have been positive, while PPPs negatively affect the tourism demand.

\section{Conclution}

Tourism has been one of the most important economic activities affected by the Covid-19 pandemic. Countries with a high share of tourism in GDP have been particularly hard hit, and this damage continues. Countries that see tourism as a strategic priority, including Azerbaijan, should pay particular attention to economic diversification, taking into account the economic impact of future similar pandemics and other shocks.

Econometric calculations show that the demand function of tourist trips to Azerbaijan varies depending on the level of income of tourists' origin countries and the price level in Azerbaijan. Unfortunately, the COVID-19 pandemic impacts not only the restriction policy of origin countries, as well as income in these countries. By decreasing the 
income levels of the population in these countries will be decreased number of tourists to Azerbaijan.

\section{References:}

[1] Lea, J. Tourism and Development in the Third World /- New York: Routledge. 1988.

[2] Samimi, A.J., Sadeghi, S., and Sadeghi, S. Tourism and Economic Growth in Developing Countries: P-VAR Approach. Middle-East Journal of Scientific Research, 10(1), 2011, p. 28-32.

[3] Sinclair, T. Tourism and Economic Development: A Survey // Journal of Development Studies, 34(5), 1998. pp.1-51.

[4] The World Bank. 2021a. - URL: https://data.worldbank.org/

[5] Crouch, G. I., Effect of income and price on international tourism. Annals of Tourism Research, 19(4), 1992, pp. 643-664.

[6] Lee, C. K., Var, T., \& Blaine, T. W., (1996). Determinants of inbound tourist expenditures. Annals of Tourism Research, 23(3), 1996, pp. 527-542.

[7] De Vita, G., The long-run impact of exchange rate regimes on international tourism flows. Tourism Management, 45, 2014, pp.226-233.

[8] Balli, F., Balli, H. O., \& Cebeci, K., Impacts of exported Turkish soap operas and visa-free entry on inbound tourism to Turkey. Tourism Management, 37, 2013, pp.186-192.

[9] Lee, C. K., Song, H. J., \& Bendle, L.J., The impact of visa-free entry on outbound tourism: A case study of South Korean travelers visiting Japan. Tourism Geographies, 12(2), 2010, pp. 302-323.

[10] Papatheodorou, A., Rosselló, J., \& Xiao, H., Global economic crisis and tourism: Consequences and perspectives. Journal of Travel Research, 49(1), 2010, pp. 39-45.

[11] Fukuda, S., Abenomics: Why was it so successful in changing market expectations? Paper presented at the TCER Conference on Abenomics, Tokyo, Japan., 2015, pp36.

[12] Economist. Winds of change: The prospects for shaking up Japanese firms have never looked so good. The Economist, London June, 2015, pp. 3.

[13] Japan National Tourist Organization, Trends of tourist arrivals. 2015, pp $16 \mathrm{http} / / \mathrm{www}$. jnto.go.jp/jpn/reference/tourism_data/visitor_tr ends/index.html

[14] De Vita, G., \& Kyaw, K. S. Tourism development and growth. Annals of Tourism Research, 60, 2016, pp.23-26.
[15] Yanling Ma, Research on the Coupling Coordinative Degree of Tourism Development and Poverty Alleviation Effects in China based on the Model of DPSIR--An Example of Guizhou, International journal of circuits, systems and signal processing, Volume 14, 2020, pp. 637-645.

[16] Tzu-Kuang Hsu, I-Hsun Tsai, The Effect of Tourism Development on Economic Growth in Taiwan: Export Growth as Mediator, International journal of circuits, systems and signal processing, Volume 14, 2020, pp. 435439.

[17] Brida, J. G., Cortes-Jimenez, I., \& Pulina, M., Has the tourism-led growth hypothesis been validated? A literature review. Current Issues in Tourism, 19(5), 2016, pp. 394-430.

[18] Tang, C. F., \& Tan, E. C., Does tourism effectively stimulate Malaysia's economic growth? Tourism Management, 46, 2015, pp.158-163.

[19] Dogru, T., \& Bulut, U., Is tourism an engine for economic recovery? Theory and empirical evidence. Tourism Management, 67, 2018, pp425-434.

[20] Mahadevan, R., Amir, H., \& Nugroho, A., Regional impacts of tourism-led growth on poverty and income inequality: A dynamic general equilibrium analysis for Indonesia. Tourism Economics, 23(3), 2017, pp.614-631.

[21] Kinseng, R. A., Nasdian, F. T., Fatchiya, A., Mahmud, A., \& Stanford, R. J., Marine-tourism development on a small island in Indonesia: Blessing or curse? Asia Pacific Journal of Tourism Research, 23(11), 2018, pp. 10621072.

[22] Habibi, F., The determinants of inbound tourism to Malaysia: A panel data analysis. Current Issues in Tourism, 20(9), 2017, pp.909-930.

[23] Gallego, Á., Rodríguez-Serrano, M. Á., \& Casanueva, C., Dynamic panel data models in tourism. Current Issues in Tourism, 22(4), 2019, pp.379-399.

[24] Kim, J., Lee, C.-K., \& Mjelde, J. W. Impact of economic policy on international tourism demand: The case of Abenomics. Current Issues in Tourism, 21(16), 2018, pp. 19121929.

[25] Liu, A., Sanshan Lin, V., \& Song, H., Analysing and forecasting tourism demand. In C. Cooper, S. Volo, W. C. Gartner, \& N. Scott (Eds.), The SAGE handbook of tourism management, 2018, pp. 202-221 
[26] Wray, M. Drivers of change in regional tourism governance: A case analysis of the influence of the New South Wales government, Australia, 2007-2013. Journal of Sustainable Tourism, 23(7), 2015, pp 990-1010.

[27] East Asia and Pacific in the Time of Covid-19. World Bank East Asia and Pacific Economic Update, (April), 2020, pp 234.

[28] Buheji, K. da Costa Cunha, G. Beka, B. Mavri_c, Y. Leandro do Carmo de Souza, S. Souza da Costa Silva, M. Hana_, and T. Chetia Yein., The Extent of COVID- 19 Pandemic Socio-Economic Impact on Global Poverty. A Global Integrative Multidisciplinary Review. American Journal of Economics, (4), 2020, pp.213-224.

[29] Fairlie, Robert. The impact of covid-19 on small business owners: evidence of early-stage losses from the April 2020 current population survey. Working Paper No. 20-022, May, 2020, pp.23.

[30] Bartik, Alexander W. Marianne Bertrand, Zoë B. Cullen, Edward L. Glaeser, Michael Luca, and Christopher T. Stanton. "How Are Small Businesses Adjus ting to COVID-19? Early Evidence from a Survey. NBER Working Paper No. w26989, 2020, pp 36.

[31] Bohn, Sarah, Marisol Cuellar Mejia, and Julien Lafortune. The Economic Toll of COVID-19 on Small Business, Public Policy Institute of California. June, 2020, pp.14.

[32] Orozco, M., Tareque, I.S., Oyer, P., and Porras, J.I., The Impact of COVID-19 on LatinoOwned Businesses, Stanford Latino Entrepreneurship Initiative, august, 2020, pp.16.

[33] State Statistical Committee of the Republic of Azerbaijan. 2020, pp 560. www.stat.gov.az

[34] Gulaliyev M.G., Ok N.I., Musayeva F.G., Efendiyev R.J., Musayeva J.G., Samira R Agayeva S.R., Economic Liberalization and Its Impact on Human Development: A Comparative Analysis of Turkey and Azerbaijan. International Journal of Environmental and Science Education. Vol.11. issue 17, 2016, pp.9753-9771.

[35] Gulaliyev M.G., Muradov R.S., Hajiyeva L.A., Muradova H.R., Aghayeva K.A., Aliyev E.S., Study of human capital development, economic indicators and environmental quality. Ekoloji, vol. 28, issue 107, 2019, pp.495-503.

[36] Selvanathan, S., Selvanathan, E.A. and Viswanathan, B. Causality between Foreign Direct Investment and Tourism: Empirical
Evidence from India, Tourism Analysis, 17(1), 2012, p. 91-98.

[37] Ruoting Zhang. Research on the Relationship between Residents' Income Growth and Tourism Consumption: A Case Study of Wuhan. Modern Economy. Vol.11 No.3, March 2020. DOI: $10.4236 / \mathrm{me} .2020 .113056$

[38] Alegre J., \& Pou, L. US household tourism expenditure and the Great Recession: An analysis with the Consumer Expenditure Survey. Tourism Economics, 2016, 22(3), 608620

[39] Khalid, U., Okafor, L. E., \& Shafiullah, M. The Effects of Economic and Financial Crises on International Tourist Flows: A Cross-Country Analysis. Journal of Travel Research, (2019). 59(2),315-334 doi: $10.1177 / 0047287519834360$

Contribution of Individual Authors to the
Creation of a Scientific Article (Ghostwriting
Policy)
Data curation, Mammadova Ulker; formal Data curation, Mammadova Ulker; formal Gulaliyev; methodology, Hajiyeva Leyla; resources, Muradova Hijran.

\section{Creative Commons Attribution License 4.0 (Attribution 4.0 International, CC BY 4.0)}

This article is published under the terms of the Creative Commons Attribution License 4.0 https://creativecommons.org/licenses/by/4.0/deed en US 